Agata Stankowska

Uniwersytet im. Adama Mickiewicza w Poznaniu

\title{
„Polonistyka w kontakcie”, czyli o przekraczaniu dyskursywnych granic
}

Zduniak-Wiktorowicz, Małgorzata. Filologia w kontakcie. Polonistyka, germanistyka, postkolonializm. Poznań: Wydawnictwo naukowe UAM, 2018. $599 \mathrm{~s}$.

Komparatystyka należy do najważniejszych, metodologicznie płodnych i inspirujących obszarów współczesnej humanistyki. Kierunki jej rozwoju poświadczają - także w obrębie badań literaturoznawczych - tendencję do stopniowego przechodzenia od studiów literackich do studiów kulturowych. Przy tym ewolucję tę widzieć należy (a w każdym razie ja skłonna byłabym tak czynić) raczej jako znak poszerzania perspektywy niż wyparcia i zastąpienia pierwszego typu badań przez drugie. Sensowność uprawiania tradycyjnych rozważań nad recepcją literacką, stanowiących nadal ważki element suplementarnych historii określonych literatur narodowych, nie zostaje tu wszak w żadnej mierze podważona, a jedynie dopełniona i ujęta w horyzoncie nowych pytań. Bodajże najważniejsze z nich dotyczy krytycznej refleksji nad dyskursami używanymi przez tak zwaną tradycyjną komparatystykę. Interesujący jest zwłaszcza problem, w jaki sposób dyskursy te wzmacniają i powielają pojęcia kluczowe dla budowania wspólnot wyobrażonych. W jaki sposób utrwalają bądź współkreują mity i języki fundamentalne dla tych wspólnot. Nieprzypadkowo przedstawiając wspomniany tu kierunek ewoluowania badań porównawczych, Andrzej Hejmej, powołując się na Gayatri Chakravorty Spivak (zob. Spivak), trafnie wskazywał, że nowo- 
czesną komparatystykę rozumieć należy jako efekt myślenia, które umożliwia dekolonizację nas samych. „Nowa komparatystyka - pisał - polega na etycznej odpowiedzialności i odkrywaniu [...] "performatywności kultur»" (Hejmej 9). W efekcie „nie może być traktowana jako dyscyplina naukowa” w tym sensie, iż „zasadza się na indywidualnym działaniu komparatysty, wrażliwości i świadomości postkolonialnej, [...] jest niekończącym się procesem translacji czy też praktyką interpretacyjną głęboko osadzoną w codziennej egzystencji”" (Hejmej 9, podkr. A.H.). Także - dodajmy - w egzystencjalnie rozumianej aktywności badawczej, która, czy sobie to uświadamiamy czy nie, staje się nieuchronnie ważnym włóknem tożsamości osoby prowadzącej takie czy inne badania. Dla współczesnego komparatysty kulturowego działalność akademicka i poszukiwania naukowe stają się tym samym w pewnej przynajmniej mierze (raczej większej niż mniejszej) elementem indywidualnie tworzonego, egzystencjalnego projektu. Postulowany wzorzec badań komparatystycznych jawi się zaś jako element dużo bardziej ogólnego wzorca - modelu odnajdywania się w interkulturowości, interesującej komparatystę jako przedmiot badań, ale przede wszystkim wybieranej przez niego jako przez człowieka za naturalny, a jednoczenie najważniejszy wymiar otaczającej go rzeczywistości. Obierany kierunek badań styka się tu tym samym - powtórzmy - z życiowym projektem takiego a nie innego sposobu bycia w kulturze. Studia $z$ dziedziny historii i teorii nauki (tu badań komparatystycznych) okazują się częścią odpowiedzi na pytanie, kim jestem i kim chciałbym być jako członek kultury rodzimej a jednocześnie jako uczestnik wielokulturowej wspólnoty.

Doskonałym przykładem takiego rozumienia nie tylko zadań, ale nade wszystko sposobu bycia nowoczesnym komparatystą stanowić może opublikowana niedawno, niezwykle interesująca książka Małgorzaty Zduniak-Wiktorowicz, zatytułowana Filologia w kontakcie. Polonistyka, germanistyka, postkolonializm (Zduniak-Wiktorowicz). Książka - dodajmy - której jedna z licznych zalet polega na tym, iż zmusza swego czytelnika, przede wszystkim akademickiego (choć nie tylko), do autokrytycznej refleksji.

Już w samym tytule monografii nakreślony zostaje wspomniany wyżej tyleż naukowy, co egzystencjalny projekt młodej poznańskiej badaczki. Zamysł, który narodził się rzecz jasna w odpowiedzi na jej własną akademicką ścieżkę, świadomie rozwijaną i osadzoną w określonej kulturowo przestrzeni, czyli w tym wypadku geograficzno-historyczno-mentalnej sferze pogranicza polsko-niemieckiego, które samo w sobie stanowi wyzwanie ze względu na różne „bolesne złogi” dzielące, ale i łączące narody żyjące po obu stronach Łaby. Badawczo-egzystencjalny projekt, jaki wyłania się z lektury opisywanej monografii, jest - czego czytelnik domyśla się nawet bez znajomości biograficznej 
faktografii - efektem pracy Zduniak-Wiktorowicz „na granicy”. Badaczka otwarcie (choć nienachalnie) tematyzuje zresztą tu i ówdzie tę właśnie formę swojej naukowej biografii. Czyni ją przedmiotem przede wszystkim metodologiczno-deskryptywnej refleksji, ale - co ważniejsze - traktuje ją jako punkt wyjścia do stworzenia postulatywnej formuły badań wielopoziomowych interferencji między filologiami narodowymi, uprawianymi w ojczyznach poszczególnych badaczy i poza ich granicami. Formuły, dodajmy, wskazywanej przez Zduniak-Wiktorowicz jako jeden z możliwych, a ze wszech miar pożądanych sposobów bycia w kulturze pogranicza, tu polsko-niemieckiego i niemiecko-polskiego, slawistyczno-germanistycznego i germanistyczno-slawistycznego. Na czym kreślony w książce projekt miałby polegać i do czego prowadzić?

Odpowiadając na te dwa zasadnicze pytania, zacząć wypada od uwag najbardziej ogólnych, dotyczących przedstawianej monografii jako świadectwa performatywnego działania autorki książki w kulturze. Filologia w kontakcie, licząca bez mała sześćset stron dużego formatu, składa się z dwu zasadniczych części, zatytułowanych „Polonistyka i germanistyka” oraz „Polsko-niemieckie postzależności”. Głównym przedmiotem obu fragmentów monografii jest refleksja nad obrazem kulturowych relacji między Polską a Niemcami. Wzajemnych odniesień utrwalonych w dyskursach, które wykorzystują i współtworzą dwie sąsiedzkie (w sensie usytuowania przestrzennego i historycznego) filologie: polska i germańska. Filologie - co nie bez znaczenia - mające różne, często zaskakująco silnie odseparowane od siebie obiegi: krajowy i zagraniczny i wchodzące (lub - nad czym autorka słusznie ubolewa - niedostatecznie silnie wchodzące) w rozmaite interferencje także na styku szeroko ujętych badań slawistycznych i germańskich. W punkcie wyjścia swoich rozważań autorka stawia pytanie: na ile i czy w ogóle dyskursy współtworzone w ramach tych odmiennych obiegów filologii narodowych, figur i języków, jakimi posługują się uprawiający je badacze, odzwierciedlają postkolonialne i postzależnościowe relacje między Polską i Niemcami? I - uprzedźmy - w toku szczegółowych interpretacji odpowiada na nie twierdząco, zbierając argumenty na rzecz tezy, iż języki używane przez slawistów niemieckich i polskich nie tylko je odbijają, ale też nierzadko mniej lub bardziej świadomie podtrzymują. Zduniak-Wiktorowicz stawia przy tym generalną tezę, że gdyby przeczytać interesujące ją teksty tak, jak to sama proponuje, jako świadectwa mentalności i wyobraźni symbolicznej ich akademickich autorów, z ujęciem metodologii wypracowanych na gruncie badań postkolonialnych i postzależnościowych, to polscy i niemieccy literaturoznawcy mogliby się o sobie dużo dowiedzieć, oczyścić sferę postzależnościowych i postkolonialnych przedzałożeń, a w efekcie stworzyć pole do uprawiania wolnej od nich „filologii w kontakcie”. Tak przynajmniej rozumiem generalne założenie, jakie autorka 
przyjmuje w toku swoich poszukiwań. Idea to niewątpliwie kusząca i piękna w swym idealistycznym założeniu. Czy całkowicie wolna od zagrożeń, którym badaczka pragnie dać opór, nie jestem już pewna, ale o tym za chwilę.

Podkreślić trzeba, że Zduniak-Wiktorowicz podchodzi do postawionego sobie zadania profesjonalnie wyposażona, gromadząc imponującą swym rozmiarem literaturę (polsko- i niemieckojęzyczna bibliografia przedmiotowa i podmiotowa, wykorzystana w jej monografii, liczy kilkaset pozycji), a także przygotowując funkcjonalny i metodologicznie spójny warsztat. Tak wyekwipowana postanawia poddać wnikliwej, a znaczy to krytycznej lekturze symboliczne imaginaria polonistów i germanistów, uprawiających swe filologiczne poletka. Bierze przy tym pod swą badawczą, postzależnościową lupę zarówno dokonania germanistów i polonistów w Polsce, jak też germanistów/slawistów i polonistów w Niemczech oraz, na zasadzie krótkich ekskursji, także wybrane prace germanistów i polonistów/slawistów powstałe w krajach anglojęzycznych, szczególnie w Stanach Zjednoczonych Ameryki. Autorka nie czyta w zasadzie tekstów literackich (wyjąwszy te o charakterze autobiografii naukowych, reportaży autoetnograficznych i nielicznych przykładów literatury migracyjnej), lecz w przeważającej mierze teksty powstałe w ramach uprawiania humanistyki akademickiej. Nadmienię tu, że przyjęte przez badaczkę w tym względzie proporcje wydają mi się niekorzystne dla oceny obrazu polsko-niemieckich i niemiecko-polskich relacji, który wyłania się z jej ciekawej rozprawy. Może jest tak, jak skłonna byłabym sądzić, że literatura piękna jest bardziej zaawansowana w budowaniu sfery pożądanego kontaktu między sąsiedzkimi imaginariami symbolicznymi - polskim i niemieckim - niż działania akademickie? A może się mylę i jest właśnie na odwrót? Nie sposób powziąć na ten temat jakiś podejrzeń, a tym bardziej rozstrzygnąć postawionej kwestii, decydując się na tak dalece niesymetryczne zestawienie „tekstów akademickich” i literatury pięknej. Ale to uwaga marginalna. Gdyby autorka miała zadość uczynić mojemu niedosytowi, napisać by musiała kolejnych kilkaset stron.

Nie dziwi zresztą, że Zduniak-Wiktorowicz interesują przede wszystkim wypowiedzi akademików. Pisze bowiem $\mathrm{w}$ istocie rozprawę $\mathrm{z}$ historii i teorii nauki. Czyta zarówno autotematyczne prace, podejmujące zagadnienia transdyscyplinarności i refleksje na temat inspiracji metodologicznych przejmowanych z zagranicy, a także świadectwa współpracy z filologami sąsiednich państw, jak i kulturoznawcze i literaturoznawcze teksty tych polskich, niemieckich i amerykańskich germanistów, polonistów, slawistów, którzy działają w obszarze postcolonial studies i studiów postzależnościowych. Badaczka przenosi tė̇ często uwagę (co nota bene potwierdza po raz kolejny wagę homologii miedzy projektami badawczymi a egzystencjalnymi) z samych tekstów na ich autorki 
i autorów, analizując sposoby, w jakich odnajdują się oni w sytuacji niełatwego, jeśli wspomnieć historyczne wydarzenia łączące dzieje Polski i Niemiec, sąsiedztwa. Sąsiedztwa, które właśnie jako takie - trudne i pełne „historycznych złogów" - stawia przede wszystkim ludziom kultury, akademikom, literaturoznawcom wyzwanie do pracy na rzecz nie tylko powierzchownego pojednania. Wyzwanie do cierpliwego uczestniczenia w ruchu, który nie jest w pełni możliwy bez wielokrotnie ponawianej (auto)krytycznej refleksji nad własnymi uprzedzeniami i stereotypowymi obrazami sąsiada, a równocześnie bez spokojnego wskazania drugiej stronie, że i ona takim uprzedzeniom ulega, ugruntowując niechcący krzywdzące, kulturowe stereotypy.

Autorka Filologii w kontakcie trafnie spostrzega, że w obrębie działan akademickich nie jest to możliwe bez wysiłku przekraczania granic swych filologicznych środowisk, bez nabrania zwyczaju czytania siebie nawzajem - germanistów przez polonistów, slawistów przez adeptów German studies i vice versa. Nie jest możliwe także bez przekroczenia zwyczaju nadmiernego separowania obiegów literaturoznawstwa krajowego i zagranicznego, a także próby wyplewienia - odwołam się tu do rodzimego obszaru - poczucia wyższości polonistyki uprawianej w kraju wobec tej rozwijanej poza jej granicami.

Śladem Jürgena Joachimsthalera (Joachimsthaler) Zduniak-Wiktorowicz przekonuje o konieczności uprawiania „filologii sąsiedztwa”, „filologii - jak sama ją nazywa - w kontakcie”, co w przypadku polonisty oznaczać musi „strategiczną rezygnację z formalnego i rzeczowego polonocentryzmu” i „wyjście poza własny dyskurs wiedzy i władzy naukowej”, by stworzyć okazję do „wsłuchania się w głos Innego" (Zduniak-Wiktorowicz 66). Oznaczać musi także oczywiście analogiczne podejście po stronie niemieckich slawistów i polonistów. Autorka w toku szczegółowych zbliżeń na interesujące ją zagadnienia wskazuje - co pewnie niejednego z historyków literatury może zaniepokoić - na konieczność „odfilologicznienia” badań na rzecz pogłębiania optyki kulturowej i międzykulturowej, interdyscyplinarnej i transdyscyplinarnej. Jak wiadomo, wiązać się to może $\mathrm{z}$ trudnymi do przeoczenia stratami, ale $\mathrm{w}$ duchu uprawianej przez Zduniak-Wiktorowicz humanistyki zaangażowanej, czy - jak parafrazuje autorka termin Ewy Domańskiej - „humanistyki ratowniczej” (Domańska 12) wydaje się jak najbardziej pożądane i warte swojej ceny. Jako „polonistka krajowa” muszę napisać, że szereg myśli i wezwań formułowanych przez Zduniak-Wiktorowicz z perspektywy praktyczki polonistyki zagranicznej głęboko zapadnie mi w pamięć, stwarzając pole do przemyśleń, które z pewnością podejmę.

Postępując dalej, autorka Filologii w kontakcie przyjmuje, że wspólne pole rewizyjno-terapeutycznej, akademickiej refleksji nad relacjami Polaków i Niemców powinno, a w każdym razie mogłoby w naturalny niejako sposób powstać 
w obrębie obu filologii narodowych za przyczyną prowadzonych w nich badań postkolonialnych i postzależnościowych. Tymczasem w obrębie prac zarówno polskich polonistów, jak i niemieckich slawistów - co badaczka weryfikuje na podstawie bardzo bogatej literatury przedmiotu - dostrzegamy w tym względzie znaczące deficyty. Polskie badania postkolonialne koncentrują się przede wszystkim na kwestiach związanych z relacjami polsko-litewskimi, polsko-ukraińskimi, polsko-białoruskimi i polsko-rosyjskimi, czyli na wschodnich terenach II Rzeczypospolitej, a także na problematyce uwikłań posttotalitarnych. „Temat niemiecki - pisze Zduniak-Wiktorowicz - jest w polskich studiach postkolonialnych bardzo niedoreprezentowany" (Zduniak-Wiktorowicz 191). Jeszcze wyraźniej ową zastanawiającą lukę poświadczają prace literaturoznawców i kulturoznawców niemieckich, czego przyczyny w odniesieniu do kwestii opóźnienia w przyjęciu nowych optyk metodologicznych (tu postcolonial studies) wyjaśnia w świetnym, dołączonym do monografii studium Bożena Chołuj. Doskonale się stało, że rozważania te zostały do Filologii w kontakcie włączone. Stanowią niewątpliwie cenne dopowiedzenie do krytycznych spostrzeżeń autorki, wyjaśniając przy okazji źródła dostrzeganych przez nią zaniechań. Nade wszystko stanowią praktyczny przykład wymiany tak pożądanej, ba, kluczowej dla przedstawianego projektu interkulturowych badań i przekraczania granic własnych, lokalnie ugruntowanych dyskursów.

Mogłabym w tym miejscu nieco retorycznie zapytać, czy przyczyna niedoreprezentowania tematu niemieckiego w polskich badaniach postkolonialnych jest $\mathrm{w}$ istocie tak silnie - jak sugeruje to Zduniak-Wiktorowicz - nieuprawniona i zaskakująca. Sądzę, że nie. Krytyczny wymiar postcolonial studies najgłębszy i pożądany sens zyskuje wszak wówczas, gdy w toku prowadzonych badań dokonuje się rewizja własnych, a nie cudzych narodowych dążeń ku niewoleniu innych wspólnot - dążeń, których kolonizacyjny wymiar był dotychczas nieuświadamiany, skrywany lub wypierany. Autorefleksyjny wektor tych poszukiwań jest nie tylko oczekiwany, ale wręcz konieczny. A przecież najważniejsze polskie tematy, konieczne do przepracowania w tym względzie, łączą się niewątpliwie z Kresami/pograniczem wschodnim a nie zachodnim. Zresztą także w odniesieniu do tak zwanych terenów odzyskanych polska literatura powojenna wielokrotnie kierowała spojrzenie niepozbawione autokrytycyzmu i współodczuwającego wychylenia ku Innemu-Obcemu, odnajdując na tych terenach ślady wypędzonych. Warto wskazać tu na różnicę dzielącą utwory pisane tuż po wojnie i w czasach PRL-u oraz te powstające w ostatnich dwu dekadach wieku xx i później.

Autorka Filologii w kontakcie ma oczywiście rację, domagając się poszerzenia pól tej autokrytycznej refleksji zarówno po stronie polskiej, jak i niemieckiej. 
Remedium na „niedoreprezentowanie” tematu niemieckiego po stronie polskiej i polskiego po stronie niemieckiej widzi w podjęciu badań nad tak zwanymi „trudnymi tematami” z użyciem postzależnościowego i postkolonialnego instrumentarium. Takie bolesne „złogi historii” jak zabór pruski, wojna i okupacja, wypędzenia: „ziemie odzyskane” i „ziemie utracone”, a także powiązane z tymi doświadczeniami kwestie bycia w centrum i na peryferiach kultury, wyobrażenia Wschodu i Zachodu wpisane w symboliczne imaginaria kultury polskiej i niemieckiej, organizujące mentalność społeczeństw obu narodów, multiplikowane w literaturze i refleksji akademickiej, winny stać się - przekonuje badaczka przedmiotem namysłu, który pozwoli uwolnić i wyprowadzić wyobrażone tożsamości ze stereotypowo powielanych ujęć ofiary i opresora. Jako przykład takiego postępowania służyć mają zamieszczone w ostatniej części książki analizy i interpretacje dzieł polskich i niemieckich twórców prozy najnowszej. Zduniak-Wiktorowicz koncentruje się na wybranych utworach opublikowanych po roku 1989 - powieściach, reportażach i wypowiedziach publicystycznych Ziemowita Szczerka, Ingi Iwasiów, Olafa Müllera, Tanji Dückers, Matthiasa Nawrata i Jolanty Tabor. Na ich przykładzie opisuje poniemiecki krajobraz kulturowy, status „niewidzialnych” w Niemczech Polaków, doświadczenia twórców migrujących z Polski do Niemiec. Bardzo to wszystko ciekawe, poruszające, wartko zinterpretowane.

Zduniak-Wiktorowicz zdaje sobie oczywiście sprawę, że podejmowane przez nią w drugiej części książki tematy nie są nowe, a przywoływane przykłady tekstów literackich maja już bogatą historię interpretacji. Uczciwie referuje także wątpliwości co do wpisywania ich w obszar studiów postkolonialnych, przedstawiając stanowiska innych badaczy, choćby szczególnie niechętnych takiemu postępowaniu - Włodzimierza Boleckiego i Grażyny Borkowskiej. Badacze ci przestrzegają, nie bez powodów przecież, że „rozszerzanie pojęcia postkolonializmu na każdy kulturowy dyskurs władzy wydaje się [...] nielogicznym nadużyciem, burzącym doniosłość ustaleń Saida” (Borkowska 16). Osobiście podzielam te zastrzeżenia. Nie to jednak niepokoi mnie najbardziej.

Otóż przedstawione przez Zduniak-Wikorowicz analizy zarówno tekstów akademickich, jak i utworów literatury pięknej (tu być może właśnie za przyczyną ich stosunkowo skromnej reprezentacji) dowodzą w moim odczuciu czegoś wręcz przeciwnego wobec celu, jaki chciałaby osiągnąć badaczka, uprawiając „filologię ratowniczą”, „filologię w kontakcie” - obie służące otwieraniu i animacji ruchu prowadzącego do wyzwolenia się z kulturowych stereotypów i wpisanych w narodową i społeczną wyobraźnię (nieraz utrwalanych przez działania polityczne) symbolicznych przedznaczeń. Czytając jej frapującą książkę, wielokrotnie miałam wrażenie, że w trakcie prowadzonych rozważań 
wzmocnione zostaje to, co ma ulec obnażeniu i rewizji. Porządek analitycznych rozważań autorki Filologii w kontakcie przebiega bowiem w istocie niezmiennie od postzależnościowego założenia do postzależnościowego rozpoznania. Inaczej mówiąc, używany język współkreuje deszyfrowane zależności. Nie chcę przez to powiedzieć, że one nie istnieją, a jedynie zwrócić uwagę, że postkolonialna optyka, pozwalająca śledzić różnorakiego rodzaju resentymenty i kłopoty z tożsamością, wynikłe z kolonialnej bądź quasi-kolonialnej przeszłości i służąca intencjonalnie ich uświadomieniu i przezwyciężeniu, często sprawia, że resentymenty te ulegają paradoksalnie wzmocnieniu. Ten zaskakujący efekt emancypacyjnych i jednocześnie krytycznych działań mógłby stać się zresztą przedmiotem osobnego studium. Czy autorka skłonna byłaby dostrzec w tym względzie jakąś „winę” dyskursu postzależnościowego, który przecież w pewnej mierze (chyba często niedocenianej) utrwala antynomie, które zwalcza?! Ale tak jest w istocie z każdym dyskursem, który operując określonymi pojęciami, wydobywa i współkreuje ich obrazy w tekstach, jakie czytamy.

Jedynym wyjściem z tego ambarasu byłoby chyba uznanie, że autokrytyczny ruch, którego dokonywać miałby twórca i uczestnik „filologii w kontakcie”, musi być skierowany nie tylko wobec badanych stereotypów, ale także wobec języka ich opisu. Inaczej mówiąc, wyjście poza granice dyskursu możliwe jest tylko wówczas, gdy uświadomimy sobie wagę nieuchronnie niepełnego wymiaru tego krytycznego aktu. Pozwoli to otworzyć się na zbawienną lukę w naszych naukowych i egzystencjalnych projektach - lukę dezaktywującą tkwiące w nich dążenie do pełni i wsobności. Chodziłoby o - mówiąc jeszcze inaczej - nieustanne podtrzymywanie wyrwy we własnym języku, którą pielęgnować trzeba jako furtkę do uznania racji niewłasnych. Jest to także wyzwanie - jak pisała niegdyś Maria Janion - byśmy pozostawali „sami sobie cudzy” (zob. Janion) i starali się pisać wciąż nowe, alternatywne wersje historii w nadziei, że choć nie zmienią świata, to uchronią nas przed zniewoleniem własnym dyskursem, pozwalając trwać w drodze ku jego przekraczaniu. Lektura monografii Filologia w kontakcie. Polonistyka, germanistyka, postkolonializm podpowiada nam (choć nie zawsze wprost) tę konieczność, a jej autorka prowokuje do rozważenia wielu kwestii fundamentalnych dla uprawiania humanistyki i filologii narodowej nie tylko „na granicy”. Bez wątpienia warto mieć tę książkę na półce, a przede wszystkim w pamięci. 


\section{| Bibliografia}

Borkowska, Grażyna. „Polskie doświadczenie kolonialne”. Teksty Drugie 4 (2007). S. 40-52.

Domańska, Ewa. „Historia ratownicza”. Teksty Drugie 5 (2014). S. 12-26.

Hejmej, Andrzej. Komparatystyka. Studia literackie - Studia kulturowe. Kraków: Universitas, 2013.

Janion, Maria. Niesamowita Słowiańszczyzna. Fantazmaty literatury. Kraków: Wydawnictwo Literackie, 2006.

Joachimsthaler, Jürgen. Philologie der Nachbarschaft. Erinnerungskultur, Literatur und Wissenschaft zwischen Deutschland und Polen. Würzburg: Königshausen \& Neumann, 2002.

Spivak, Gayatri Chakravorty. Death of a Discipline. Nowy Jork: Columbia University Press, 2003.

Zduniak-Wiktorowicz, Małgorzata. Filologia w kontakcie. Polonistyka, germanistyka, postkolonializm. Poznań: Wydawnictwo Naukowe UAM, 2018.

\section{| Nota o autorze}

Agata Stankowska - prof. dr hab., zatrudniona w Instytucie Filologii Polskiej UAM, kieruje Zakładem Literatury i Kultury Nowoczesnej. Wykłada historię literatury $\mathrm{xx}$ wieku, teorię literatury i historię reprezentacji. Jest członkiem redakcji „Pamiętnika Literackiego” i redaktorem naukowym serii wydawniczej Poznańskiego Towarzystwa Przyjaciół Nauk zatytułowanej „Literatura i sztuka”. Autorka książek Kształt wyobraźni. Z dziejów sporu o wizję” i „równanie” (TAiwPN Universitas, Kraków 1998), Poezji nie pisze się bezkarnie. $Z$ teorii i historii tropu poetyckiego (Wydawnictwo Naukowe UAM, Poznań 2007), „żeby nie widzieć oczu zapatrzonych w nic". O twórczości Czesława Miłosza (Wydawnictwo Naukowe UAM, Poznań 2013), „Wizja przeciw równaniu”. Wokót popaździernikowego sporu o wyobraźnię twórcza (Wydawnictwo Poznańskiego Towarzystwa Przyjaciół Nauk, Poznań, 2013), Ikona i trauma. Pytania o „obraz prawdziwy” w liryce i sztuce polskiej drugiej połowy Xx wieku (TAiwPN Universitas, Kraków 2019). E-mail: stankowska.a@gmail.com 
